\title{
Regularities of the distribution of macrozoobenthos communities in the conditions of the rivers of Central and Northern Altai as an indicator of the ecological state of water bodies
}

\author{
Nadezhda Khudyakova, Oksana Safonova*, and Olga Vozniychuk \\ Faculty of Natural Sciences and Geography, Gorno-Altaisk State University (GASU), 649000 Gorno- \\ Altaisk, Russia
}

\begin{abstract}
In modern conditions of Gorny Altai, with an increase in anthropogenic load on the ecosystems of the region, it becomes important to assess environmental pollution. The state of the environment monitoring is a topical direction of science. The work analyzes the distribution and structural features of macrozoobenthos communities in the rivers of Altai. Revealed 25 species of invertebrate aquatic organisms belonging to 4 types and 6 classes. Benthic communities of 12 different water bodies of the Northern and Central Altai have been analyzed. Analysis of the studied structure of groups based on Euclidean distances for the shares of species in communities showed that they can be divided into three classes depending on the dominant species in them. The scheme based on the Jaccard index made it possible to reveal the influence of environmental factors that determine the structure of macrozoobenthos communities in Altai rivers. It was revealed that the anthropogenic factor has an indirect effect on the structure of communities of aquatic organisms; therefore, the macrofauna of aquatic organisms can be used as a primary indicator of the state of aquatic ecosystems.
\end{abstract}

\section{Introduction}

Gorny Altai is one of the most beautiful regions of Russia; it is considered an ecologically clean area. At the same time, in recent years, there has been an increase in anthropogenic, in particular recreational, tourist load on the region, which affects natural ecosystems. That is why in modern conditions the problems of environmental pollution are very important. Assessment and monitoring of the state of the environment is a topical direction of science. One of the important process is biological monitoring, which tracks changes in the states of populations of living organisms, organisms individually, and also the species composition of biotopes and their prediction. To assess the state of the environment, the species of living organisms that are most sensitive to changes in environmental factors are used. In the aquatic

\footnotetext{
*Corresponding author: oksvarias@mail.ru
} 
environment, the most frequently used bioindicators are representatives of macrozoobenthos $[1,2,3]$.

There is a fairly extensive global experience in assessing the state of aquatic ecosystems using bioindication methods, but the most noticeable and important is the assessment of biodiversity and primary relative to other characteristics $[2,4]$. However, on the territory of Gorny-Altai, such studies were carried out only on large and relatively large rivers $[5,6]$. On the other hand, the study of communities and ecosystems is an urgent area of research in modern ecology. The main task of the work ahead is to identify the regularities of the distribution of fauna and the structure of communities of macrozoobenthos of the Altai rivers, depending on the state of ecosystems.

\section{Material and methods}

The work is based on data collected in the summer of 2017 in the regions of the Altai Republic: Maiminsky, Chemalsky, and Ongudaysky. 12 stations were examined, 25 species of aquatic organisms were found. The reservoirs and stations where the studies were carried out differed in a number of parameters: current speed, water temperature, eutrophication, topography, and bottom structure. The pollution of habitats and the degree of anthropogenic impact were taken into account. Of the surveyed stations, 4 are places with strong, 2 with weak, and 6 places with moderate anthropogenic impact (Figure 1).

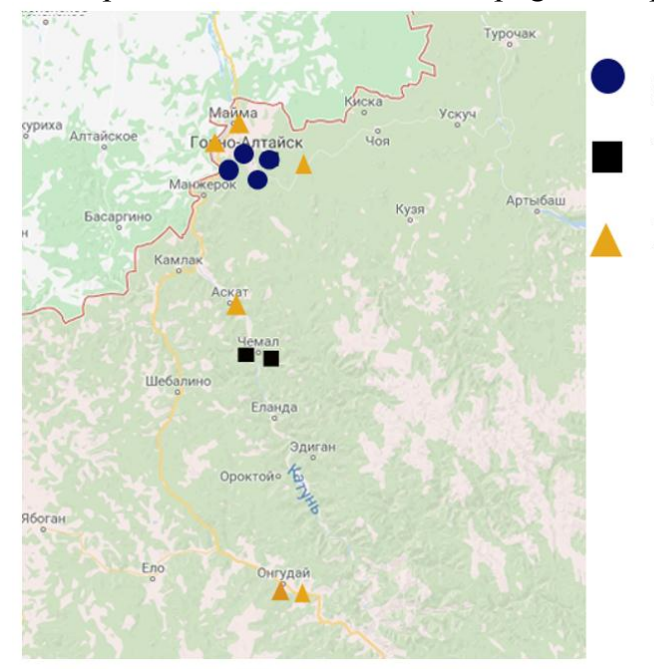

Strong anthropogenic impact

Weak anthropogenic impact

Moderate anthropogenic impact

Fig. 1. Map of the study area with indication of the places of registration and their characteristics.

The method of collecting the fauna of aquatic organisms at the sites was taken from the works of M.V. Chertoprud [7]. The collection was carried out with three samples in closely spaced sites with an area of $0.25 \mathrm{~m}^{2}$ (with further recalculation per $1 \mathrm{~m}^{2}$ ). Organisms are harvested with a scraper from the ground and manually from large stones. To determine the specificity of the studied communities of macrozoobenthos of various rivers of Altai, a scheme was used, constructed using the Ward's method based on Euclidean distances for the shares of species in the described communities.

\section{Results and discussion}

The study of the spatial distribution of communities and ecosystems is an urgent direction of research in modern ecology. A lot of works $[8,9]$ are devoted to the establishment of 
regularities of the spatial distribution of different groups of terrestrial animals, there are also works devoted to changes in ecosystems of Altai under the influence of recreational impact [10]. A similar approach to the study of aquatic organisms is also an urgent direction. The Altai rivers are heterogeneous in many parameters and the study of the distribution patterns of macrozoobenthos communities in them is of scientific interest.

First of all, it is necessary to consider the spatial distribution of communities of aquatic organisms in different ecological conditions of Altai.

On the territory of the middle mountains of the Central Altai, we examined two water bodies. The largest of them is the Ursul River, flowing in the territory of the village of Ongudai. Samples were taken in an area with artificial stone embankments along the banks, almost without vegetation. The bottom of the reservoir is also rocky with a small amount of large sand particles. The water is cloudy. The current speed is $0.33 \mathrm{~m} / \mathrm{s}$. The invertebrate fauna of the benthos of this river is made up of 10 species belonging to 2 types. Insects, represented by larvae developing in water, predominate. The most widespread is the Potamanthus luteus. The rest of the species are more rare or even isolated.

The total population density of invertebrates in this reservoir is 67.2 individuals per $\mathrm{m}^{2}$. Potamanthus luteus (29.76\% of the total density), the Brachycentrus subnubilis (19.68\%) and Stenopsyche (11.9\%) dominate in the studied community (Table 1).

Table 1. The structure of macrozoobenthos communities in rivers in the middle mountains of Central Altai (ind. $/ \mathrm{m}^{2}$ ).

\begin{tabular}{|l|c|c|}
\hline \multirow{2}{*}{ Invertebrate species } & \multicolumn{2}{|c|}{ River names } \\
\cline { 2 - 3 } & Ongudayka & Ursul \\
\hline Lymnaea auricularia & - & 0.15 \\
\hline Lymnaea peregra & - & 9.54 \\
\hline Potamanthus luteus & 61.44 & 29.76 \\
\hline Leuctra sp. & 6.42 & 5.95 \\
\hline Dirura sp. & 0.07 & 9.55 \\
\hline Chironomus sp. & 4 & - \\
\hline Cheumatopsyche lepida & - & 7.73 \\
\hline Brachycentrus subnubilis & 0.07 & 19.68 \\
\hline Halesus sp. & - & 5.59 \\
\hline Glossosoma vernalet & 28 & 0.15 \\
\hline Stenopsyche sp. & - & 11.9 \\
\hline
\end{tabular}

The species composition of benthic invertebrates of the Ursul River is quite rich; here, species not typical for the Ongudayka, a smaller river in the region, are noted (Table 1).

In general, the composition of the macrozoobenthos fauna of the described river suggests that this reservoir is relatively clean, this is indicated by the presence of Caddisflies, which prefer clean flowing waters. However, it should be noted that there is an insignificant presence of species inhabiting silted sites rich in organic matter (Chironomus, Lymnaea auricularia, Lymnaea peregra). Nevertheless, since the density of these species is extremely low, they do not play a significant role in the described grouping. According to our observations, they are confined to small coastal areas with a small current.

The biomass of benthic invertebrates in the reservoir is about $0.75 \mathrm{~g} \mathrm{per} \mathrm{m}^{2}$, which, however, allows us to consider these invertebrates a sufficient food supply for the fish living here.

A smaller reservoir is the Ongudayka River, which flows through the territory of the settlement. It has rocky embankments and a bottom with coarse grains of sand. The water is cloudy. The current speed is $0.6 \mathrm{~m} / \mathrm{s}$. In total, 7 species were found in this biotope. Insects, represented by larvae developing in water, predominate. The most widespread is the 
Potamanthus luteus. The rest of the species are rarer. The total population density of invertebrates in this reservoir is 102 individuals per $\mathrm{m}^{2}$. Potamanthus luteus $(61.44 \%$ of the total density) and the Trichoptera dominate in the studied community.

The composition of the fauna of macrozoobenthos, a tributary of the Ursula - the Ongudayki River suggests that this reservoir is relatively more polluted than the previously described Ursul River, this is indicated by the presence in a significant amount of the Chironomus, which prefers flowing waters rich in organic matter and absent in Ursula.

Despite the fact that the Ongudayka flows into the Ursul River, the species inhabiting these biotopes do not coincide. Concurrent species are common in many biotopes.

Three water bodies were surveyed on the territory of the middle mountains of the Northern Altai. The largest of them was the Katun River. In the section of the river flowing on the territory of Chemal, samples were taken on a relatively steep bank, rocky, with rock outcrops. The bottom is sandy with small stones, but sometimes large stones were also found. The water is cloudy. The river speed is $0.5 \mathrm{~m} / \mathrm{s}$. 6 species of invertebrates belonging to 2 types have been identified. Insects, represented by larvae developing in water, predominate. The total population density of invertebrates in this reservoir is 1.1 individuals per $\mathrm{m}^{2}$. Dominated in the community under study is the Brachycentrus subnubilis (13.64\% of the total density), Perla abdominalis (59.9\%) (Table 2).

Table 2. The structure of communities of macrozoobenthos in the rivers of the middle mountains of the Northern Altai (ind. $/ \mathrm{m}^{2}$ ).

\begin{tabular}{|l|c|c|c|}
\hline \multirow{2}{*}{ Invertebrate taxa } & \multicolumn{3}{c|}{ River names } \\
\cline { 2 - 4 } & Chemalka & Katun & Askatka \\
\cline { 2 - 4 } & - & 6.82 & 0.36 \\
\hline Gammarus sp. & 2.97 & 6.82 & 19.21 \\
\hline Potamanthus luteus & - & - & 11.44 \\
\hline Ephemerella sp. & - & 6.82 & - \\
\hline Leuctra sp. & - & 59.09 & - \\
\hline Perla (Capnia) sp. & 4.45 & - & 11.44 \\
\hline Chironomus sp. & 7.43 & - & - \\
\hline $\begin{array}{l}\text { Hydropsychidae } \\
\text { (Cheumatopsyche lepida) }\end{array}$ & - & - & 19.21 \\
\hline Goera pilosa & 44.58 & - & - \\
\hline Glossosoma vernalet & 40.56 & 13.64 & 38.41 \\
\hline $\begin{array}{l}\text { Brachycentrus subnubilis } \\
\text { Brachycentrus subnubilis) }\end{array}$ & 0.03 & 6.82 & - \\
\hline Hydroptila sp. & 0.03 & - & - \\
\hline Stenopsyche sp. & & & \\
\hline
\end{tabular}

Samples in the Chemalka River were taken on the territory of the Chemal settlement, not far from the confluence of the Chemal hydroelectric power station into the reservoir. The shore on the site is flat, rocky, the stones are large. The bottom is made of large and mediumsized rounded stones. The water is clear. The speed of the water flow is $0.6 \mathrm{~m} / \mathrm{s}$. The depth of the reservoir is up to $0.7 \mathrm{~m}$.

On this river, the fauna of invertebrates of benthos consists of 7 species belonging to type 1 , and represented by insects, namely, larvae developing in the water. There were no species recorded in all the studied benthic samples, but the most widespread were Potamanthus luteus and Leuctra. The total population density of invertebrates in this reservoir is 269.4 individuals per $\mathrm{m}^{2}$. The Brachycentrus subnubilis (19.68\%) and Stenopsyche (11.9\%) dominate in the studied community.

The small shallow river Askatka, flowing in the territory of the village of Askat, has a 
bottom of large stones. The water is cloudy. The banks are a degraded forb meadow. The current speed is $1.25 \mathrm{~m} / \mathrm{s}$. There are 6 species of invertebrates belonging to 2 types. Insects, represented by larvae developing in water, predominate. There were no species recorded in all the studied benthic samples, but the most widespread were Brachycentrus subnubilis and Potamanthus luteus The total population density of invertebrates in this reservoir is 11.5 individuals per $\mathrm{m}^{2}$. TheBrachycentrus subnubilis $(40.56 \%$ of the total density) and Big Stenopsyche $(11.9 \%)$ dominate in the studied community (Table 2$)$.

In all surveyed habitats on the territory of the middle mountains of Northern Altai, only two species were found inhabiting all three water bodies. These species are Brachycentrus subnubilis and Potamanthus luteusю The most productive habitat is the Chemal River.

In the low mountains of the Northern Altai, we studied 7 reservoirs. Among them there are both large and small rivers. The largest of them are the Katun and Maima rivers. The Maima River was surveyed at two sites: on the territory of the city of Gorno-Altaysk and on the territory of the village of Kyzyl-Ozek. On the territory of Gorno-Altaysk, samples were taken in an area under strong anthropogenic influence. The banks are artificial embankments. The bottom is rocky, made of large stones. The water is cloudy. The current speed is 0.45 $\mathrm{m} / \mathrm{s}$.

The invertebrate fauna of the benthos of this river is made up of 10 species belonging to 2 types. There were no species recorded in all the studied benthic samples, but the Leuctra was the most widespread. The most numerous species in this community are: Potamanthus luteus, Leuctra $(51.36 \%)$ and Goera pilosa $(17.92 \%)$. The rest of the species are rarer. The total population density of invertebrates in this reservoir is 18.2 individuals per $\mathrm{m}^{2}$.

The Maima River in the territory of the village of Kyzyl-Ozyok has a bottom of large and medium stones, and a small amount of silt between them. This station was subject to slight anthropogenic impact. The speed of the water flow is $0.6 \mathrm{~m} / \mathrm{s}$. We found only 3 species in this area. The most numerous species in this community are: Potamanthus luteus (46.94\%) and Leuctra $(40.87 \%)$.

The Ulala River flows within the city limits and is considered a polluted reservoir. The banks are overgrown artificial embankments. The water is cloudy. The current speed is 0.76 $\mathrm{m} / \mathrm{s}$. In total, 8 species of invertebrates belonging to 2 types were found. Dominated here were the Cheumatopsyche lepida (52.65\%), Gammarus (14.88\%) and Goera pilosa (11.44\%).

Table 3. Species composition of macrozoobenthos in the area of the city of Gorno-Altaysk and neighboring villages.

\begin{tabular}{|l|c|c|c|c|c|c|c|}
\hline \multicolumn{1}{|c|}{ Type } & Bochk & MGA & UI & MKO & KM & EI & K \\
\hline Polycelis nigra & 12.66 & - & - & - & - & - & - \\
\hline Glossiphonia complanata & - & - & 0.21 & - & - & - & - \\
\hline Lymnaea auricularia & - & 0.11 & 6.87 & - & 0.29 & - & - \\
\hline Lymnaea peregra & - & - & 6.87 & - & - & 0.17 & - \\
\hline Amphipepelea glutinosa) & - & - & - & - & 0.29 & - & - \\
\hline Ancylus fluviatilts & - & - & - & - & 0.29 & - & - \\
\hline Gammarus sp. & 39.56 & - & 14.88 & - & - & 55.21 & 86.49 \\
\hline Potamanthus luteus & 0.15 & 17.92 & 0.21 & 46.94 & 25.49 & - & 4.89 \\
\hline Ephemerella sp. & 39.56 & - & - & - & - & - & - \\
\hline Leuctra sp. & - & 51.36 & - & 40.87 & 73.31 & 44.33 & - \\
\hline Nepa cinerea & - & - & - & 12.24 & - & - & 0.15 \\
\hline Chironomus sp. & - & 5.97 & 6.87 & - & - & 0.17 & 0.15 \\
\hline Cheumatopsyche lepida & - & 5.97 & 52.65 & - & - & - & 0.15 \\
\hline Goera pilosa & - & 17.92 & 11.44 & - & - & - & 8.15 \\
\hline Limnophilus imcisus & 7.91 & - & - & - & - & - & - \\
\hline Rhyacophila sp. & - & 0.75 & - & - & - & - & - \\
\hline Halesus sp. & - & - & - & - & 0.29 & - & - \\
\hline
\end{tabular}




\begin{tabular}{|l|c|c|c|c|c|c|c|}
\hline Phlebotomus motauus & 0.15 & - & - & - & - & - & - \\
\hline Polycentoronyc sp. & - & - & - & - & - & 0.17 & - \\
\hline
\end{tabular}

The Katun River, in its lower course, flowing in the village of Maima, has a sandy shore, a rocky bottom with silty sediment. The water is cloudy. The current speed is $0.43 \mathrm{~m} / \mathrm{s}$. At this station, 6 species of 2 types were found. The most widespread in the samples were: Leuctra (73.31\%) and Potamanthus luteus (25.49\%).

The Kayas River flowing through the territory of the city of Gorno-Altaysk is exposed to a fairly strong anthropogenic impact. The bottom is rocky, made of large and small stones. The banks are a degraded meadow. The water is cloudy. The speed of the water flow is 0.4 $\mathrm{m} / \mathrm{s}$. 6 species were found in this area. The most widespread is the Gammarus (86.4\%), the smallest are the Chironomus and the Cheumatopsyche lepida $(0.15 \%)$.

One of the smallest of the studied reservoirs was the Elanda Creek. The water in it is clear, the bottom is rocky. The current speed is $0.38 \mathrm{~m} / \mathrm{s}$. In total, we found 5 species in this biotope. The most common are: Gammarus (55.21\%) and Leuctra (44.33\%).

And the last station on the territory of the city of Gorno-Altaysk is a stream in the Bochkarevka microdistrict, flowing in the mountains, outside the village. This is a shallow mountain stream. The water is turbid, the current speed is $0.11 \mathrm{~m} / \mathrm{s}$. We met only 6 species in this biotope, the most common are: Ephemerella (39.56\%), Gammarus(39.56\%) and Polycelis nigra (12.66\%).

All the studied habitats on the territory of the low mountains of Northern Altai are extremely heterogeneous; therefore, no species living in all the studied rivers were found. The most widespread species is the Potamanthus luteus. The rest of the species are less common.

In general, the studied biotopes are distinguished by a high species diversity in the communities of benthic forms of aquatic organisms. The richest species composition is typical for the community of the Ursul River ( 9 species), the smallest number of species was recorded in the Maima River, in the vicinity of the village of Kyzyl-Ozek (3 species in total).

The most common species in the studied water bodies are the following species: Potamanthus luteus (recorded in 8 stations) and Leuctra (in 7 habitats). In spite of their wide distribution, these species have different degrees of influence on the structure of communities. They can act as dominants or be singular. In addition, species with a local distribution were noted, only in the Katun River in the territory of the village. Molluscs the Ancylus fluviatilts and Amphipepelea glutinosa were recorded in Maima.

To assess the influence of factors on the species composition of the Altai macrozoobenta rivers, a classification of the studied communities is proposed, based on the share of individual species in them. Such a classification is a scheme drawn up on the basis of cluster analysis of the structure of macrozoobenthos groups, which is based on the Ward's method for Euclidean distances.

Classes were allocated if the values of Euclidean distances were more than 1 , and subclasses - if the value was 0.8 . As a result, all the communities of the rivers of Northern and Central Altai studied by us and described above, depending on their species composition and structure, can be combined into 3 classes (Figure 2), within which a number of subclasses are distinguished.

I. Cold mid-mountain rivers. The studied rivers of the Chemal and Ongudaysky regions belong to this class. These are mountain rivers, characterized by cold water with a fast current and rocky bottom, a high degree of aeration, and low eutrophication. All communities of aquatic organisms of this class can be divided into 2 subclasses, depending on the predominant species in them:

1. Quite extensive, includes communities of 4 rivers, both Central and Northern Altai. 
The communities of macrozoobenthos are most similar to each other in the rivers of Central Altai, in which the Potamanthus luteus dominates, and the Leuctra plays a significant role with it, with the general similarity of the fauna.

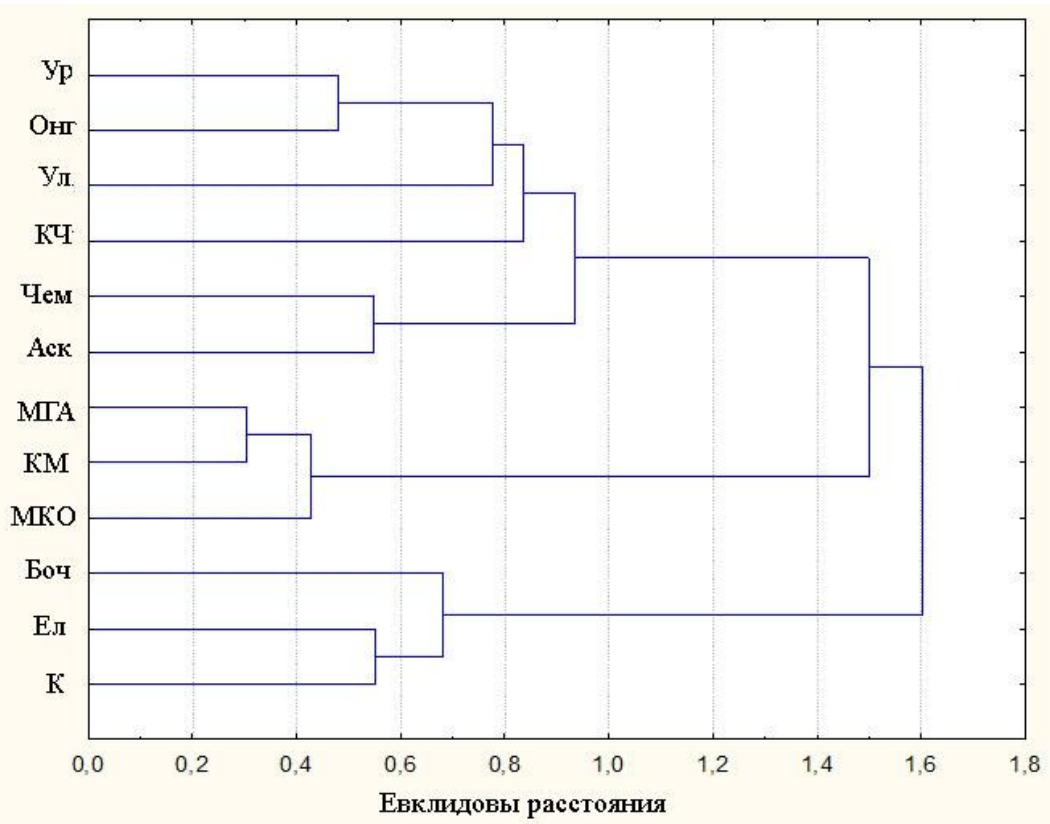

Fig. 2. Dendrogram of similarity. Ward's method

Legend: Ur - Ursul, Ong - Ongudayka, Chem - Chemalka, KCh - Katun (Chemal village), Ask Askatka, Bochk - Bochkarevka, MGA - Maima (g. Gorno-Altaysk), UI - Ulala, KM - Katun (village of Mayma), El-Elanda, K - Kayas, MKO - Maima (village of Kyzyl-Ozek).

The other two communities, although to a large extent differ from those described, can still be attributed to this subclass. This group included the macrozoobenthos community of the Ulala River (low-mountain), which, despite the fact that it is considered polluted, but the macrozoobenthos fauna and the structure of its community, allow us to doubt this. The presence of such species as Gammarus, Cheumatopsyche lepida among the dominants, makes this reservoir close to medium-mountainous, clean rivers. This allows us to conclude that, despite mechanical pollution, the chemistry of the water is not disturbed.

2. The second subclass includes small cold rivers of the Chemal region. These rivers have a similar macrozoobenthos fauna.

II. Warm low-mountain rivers. These include: the Maima river in the village of KyzylOzyok and the city of Gorno-Altaysk and the Katun river in the village of Maima. These are quieter rivers (or river sections). They also have a rocky bottom. However, with more turbid water and noticeable esterification. Also with less aeration and higher temperature. There is also heterogeneity within this class. So in one subclass were the Maima River within the city and the Katun, which is also located within the boundaries of the settlement. And they are dominated by the Maima River, which is somewhat different in fauna composition, within the village of Kyzyl-Ozek.

III. Small eutrophied rivers. Narrow, rocky, characterized by a shallow depth, low flow rate. In spite of significant etherification, they are characterized by species that prefer clear flowing waters, such as Gammarus. The greatest similarity was observed between the communities of benthic aquatic organisms of the Yelanda and Kayas rivers; these rivers are subject to the greatest anthropogenic influence. In addition to Gammarus, they are dominated by eurytopic species. This group also adjoins the community of the cleaner Bochkarevka 
River, which is explained by the predominance of the Gammarus, but its subdominants are the Ephemerella and Polycelis nigra, which are characteristic of alpine water bodies.

Another effective method for identifying environmental factors affecting their spatial distribution is the construction and analysis of graphs using the Terent'ev Pleiades method. It is used to identify trends in species composition change depending on river types and environmental conditions (Figure 3).

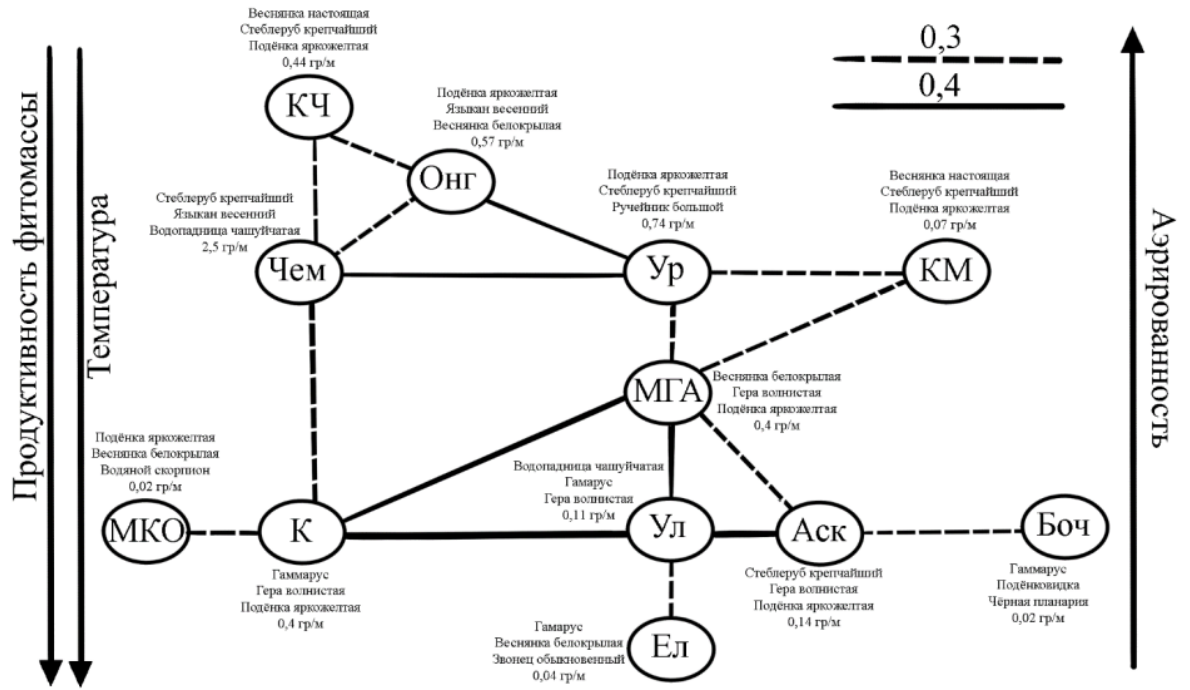

Fig. 3. Biotope distribution graph by the similarity of the macrozoobenthos

Legend: Ur - Ursul, Ong - Ongudayka, Chem - Chemalka, KCh - Katun (Chemal village), Ask Askatka, Bochk - Bochkarevka, MGA - Maima (g. Gorno-Altaysk), UI - Ulala, KM - Katun (village of Mayma), El-Elanda, K - Kayas, MKO - Maima (village of Kyzyl-Ozek).

Structural graphs were built reflecting the influence of such factors as: productivity of phytomass, aeration of the reservoir and ambient temperature. For identical biotopes, we took those that had a Jaccard index of 0.4 and higher, less related ones - 0.3. Relationships between biotopes with a Jaccard index of 0.2 and below were not considered as insignificant.

The constructed graphs revealed two types of the macrozoobenthos population. The first type is typical for communities of cold high-mountain rivers with a fast current, high aeration, and low eutrophication. This group of rivers includes the communities of macrozoobenthos of hydrobionts of such rivers as: Ongudayka, Chemalka, Katun in the villages of Chemal and Ursul. The second type is represented by communities of low-mountain rivers, warmer, with a slower flow, respectively, less aeration and more eutrophication. The rivers with this population group include: the Maima river in Gorno-Altaysk, Kayas, Askatka (due to such species as Gammarus, Potamanthus luteus, Goera pilosa and Chironomus), and the Katun in the village of Maima and in the village of Chemal were included in a separate group.

The presented graphs clearly show the presence of three trends. The first trend is noted for the productivity of phytomass and, accordingly, for the level of eutrophication and runs in the direction from the communities of hydrobionts of the Katun River in Chemal to the invertebrates of Elanda. It has been shown that small rivers that look clean on the outside actually contain productive biomass in the form of algae, unicellular and other organisms.

The second trend tracks temperature changes and coincides with the previous one. The temperature rises from high-mountainous rivers to shallow water bodies. And the third reverse trend is the current speed, which increases near high-mountain rivers. And accordingly, the aeration of relatively slowly flowing rivers increases.

From the graphs obtained earlier, it was revealed that there is no direct anthropogenic impact on the structure of the population of macrozoobenthos. However, in some factors, the 
impact of anthropogenic load becomes more noticeable. For example, the high-mountainous clear river Ursul within the village of Ongudai, due to the influence of the anthropogenic factor, has participants with increased eutrophication and due to this it is located closer to the Maima River in the territory of Gorno-Altaysk. A similar picture is observed in the Askatka River, which is perceived as a relatively clean shallow river, but since it flows within a settlement, it has significant eutrophication. Therefore, in the diagram, it is shifted down to low-mountain rivers.

\section{Conclusions}

Thus, as a result of the study carried out in the water bodies of the Northern and Central Altai, we identified 25 species of hydrobionts belonging to 4 types and 6 classes. The richest species composition is typical for the Ursul River (10 species). The least rich species composition is typical for the section of the Maima River, located in the territory of the village of KyzylOzek (3 species).

Analysis of the structure of macrozoobenthos groups in Altai rivers based on Euclidean distances for the shares of species in communities showed that all groups of aquatic organisms are divided into three classes depending on the dominant species. The above classification by species composition revealed the influence of environmental factors that determine the structure of macrozoobenthos communities in Altai rivers. The most significant factors are: eutrophication, temperature and aeration. At the same time, the anthropogenic factor has an indirect effect on the structure of communities of aquatic organisms; therefore, the macrofauna of aquatic organisms can be used as a primary indicator of the state of aquatic ecosystems.

\section{References}

1. E.V. Rassadina, Vestnik Ul'yanovskogo gosudarstvennoj sel'skohozyajstvennoj akademii, IV Aktual'nye voprosy veterinarnoj mediciny, biologii i ekologii, 48 (2007)

2. V.A. ZHigul'skij, V.F. SHujskij, N.A. Solovej, N.S. Car'kova, Bioraznoobrazie nazemnyh i vodnyh zhivotnyh $\mathrm{i}$ zooresursy, 1 vserossijskaya nauchnaya Internetkonferenciya: materialy konf. Kazan', 64 (2013)

3. S.A. Nefedova, A.A. Korovushkin, D.G. Minin, L.B. Zutova, I.A. Ipatov, Teoreticheskaya i prikladnaya ekologiya, 3, 14 (Kirov: Izdatel'skij Dom "KAMERTON", 2014)

4. Juan David Gutiérrez, Wolfgang Riss, Rodulfo Ospina, Acta biol. Colomb., 7(2), 37 (2002)

5. L.V. Vesnina, N.N. Ershov, YA.S. Pyatkova, K.A. Kuznecova, Bioraznoobrazie, problemy ekologii Gornogo Altaya i sopredel'nyh territorij, nastoyashchee, proshloe, budushchee, Materialy IV mezhdunarodnoj konferencii, 46 (Gorno-Altajsk: RIO GAGU, 2016)

6. L.V. Vesnina, A.YU. Lukerin, A.V. Mihajlov, Bioraznoobrazie, problemy ekologii Gornogo Altaya i sopredel'nyh territorrij: nastoyashchee, proshloe, budushchee. Materialy IV mezhdunarodnoj konferencii, 48 (Gorno-Altajsk: RIO GAGU, 2016)

7. CHeroprud M. V. Palatov D.M., Biologiya vnutrennih vod, 3, 46 (M.: Nauka, 2017)

8. A.G Larionov, L.G. Vartapetov; pod red. L.G. Vartapetova, Trudy instituta sistematiki i ekologii zhivotnyh SO RAN, 47, Pticy Sibiri: struktura i dinamika fauny, naseleniya i populyacii, 133 (M.: Tovarishchestvo nauchnyh izdanij KMK, 2011) 
9. S.V. Dolgovyh, Vestnik Tomskogo gosudarstvennogo universiteta: Obshchenauchnyj periodicheskij zhurnal, Byulleten' operativno nauchnoj informacii, Ocenka bioresursov transgranichnoj biosfernoj territorii (TBT): Rossiya, Mongoliya, Kazahstan, Kitaj CHast' 2, 26 (Tomsk: Tomskij gosudarstvennyj universitet, 2006)

10. P. Malkov, M. Sukhova, O. Vozniychuk, A. Malkova, N. Khudyakova, S. Dolgovykh, Journal of Environmental Management and Tourism, 10(4), 870 (2019) 